\title{
Changes in Abscisic Acid Levels, Ethylene Biosynthesis, and Protein Patterns during Fruit Maturation of 'Granny Smith' Apples
}

\author{
I. Lara \\ Centre UdL-IRTA, Alcalde Rovira Roure 177, 25198 Lleida, Spain \\ M. Vendrell ${ }^{1}$ \\ CID-CSIC, Jorge Girona 18-26, 08034 Barcelona, Spain
}

\begin{abstract}
AdDitional INDEX WORDs. 1-aminocyclopropane-1-carboxylic acid, ACC oxidase, ACC synthase, Malus sylvestris var. domestica

ABstract. Endogenous ABA, free and conjugated ACC concentrations, ethylene-forming capacity (EFC), and presence of ACC oxidase (ACO) and ACC synthase (ACS) proteins were monitored during the preharvest maturation period of ' $G$ ranny Smith' apple fruit (Malus sylvestris L. Mill. var. domestica (Borkh.) Mansf. 'Granny Smith'). Total proteins from peel and pulp tissues were also extracted at different maturity stages and separated by sodium dodecyl sulphate polyacrylamide gel electrophoresis, providing evidence of differential protein accumulation during fruit development. Endogenous ABA concentration in the peel tissue was higher than in pulp, the highest level occurring $\approx 2$ months before commercial harvest. In the pulp tissue, concomitant increases in ACC and ABA concentrations were observed, preceded by a peak in EFC. However, no ACO or ripening-related ACS proteins were detectable throughout the period considered, suggesting that very low levels of both enzymes are present during the preclimacteric stage of 'Granny Smith' apples. A hypothesis on the possible interaction between ABA and ethylene during maturation of 'Granny Smith' apples is proposed. Chemical names used: abscisic acid (ABA); 1-aminocyclopropane-1-carboxylic acid (ACC).
\end{abstract}

Ethylene plays a key role in ripening of apple fruit (Malus sylvestris var. domestica). The large increase in ethylene biosynthesis at the onset of ripening, characteristic for climacteric fruit, is believed to mediate the expression of genes involved in ripening (Speirs and Brady, 1991), and accumulation of ripening-related proteins and mRNAs have been observed in apple (Lay-Yee et al., 1990; Luetal., 1992), banana (Musa acuminata Colla)(DomínguezPuigjaner et al., 1992), tomato (Lycopersicon esculentum Mill.) (Biggs et al., 1986; Davies and Grierson, 1989; Lincoln et al., 1987; Olson et al., 1991; Smith et al., 1986), avocado (Persea americana Mill.) (Bozak et al., 1990; Tucker and Laties, 1984) and peach [Prunus persica (L.) Batsch (Peach Group)] (Callahan et al., 1989).

Other hormones may act sequentially and/or synergistically with ethylene in the maturation and ripening of fruit. ABA has been shown to interact with ethylene production, although results reported are contradictory. This hormone enhances ethylene production in apples (Vendrell and Buesa, 1989), as well as in other fruit (Brady, 1987; Riov et al., 1990) and various plant tissues (Gómez Cadenas et al., 1996; Tari and Nagy, 1996); however, it inhibits ethylene production in chickpea (Cicer arietinum L.) seeds (Díaz Miguel, 1995; Gallardo et al., 1992). Other studies have shown that ABA concentration increases during maturation of some fruit

Received for publication 23 Feb. 1999. Accepted for publication 19 Oct. 1999 This work is a portion of research submitted by I. Lara in partial fulfillment of the requirements for the $\mathrm{PhD}$ degree. The authors are grateful to $\mathrm{D}$. Dilley, Michigan State University, East Hansing, for the generous gift of apple ACO antibody, A. Latché, Ecole Nationale Supérieure Agronomique, France, for the generous present of antibodies against recombinant ACO, and S. F. Yang, Institute of Botany, Academia Sinica, Taiwan, for kindly providing apple ripening-related ACS antibody. J. Voltas is also acknowledged for statistical assistance. I. Lara was recipient of a grant from Instituto Nacional de Investigación y Tecnología Agroalimentaria (INIA), Madrid, Spain. This work was supported by project INIA-9672, financed by INIA. The cost of publishing this paper was defrayed in part by the payment of page charges. Under postal regulations, this paper therefore must be hereby marked advertisement solely to indicate this fact.

${ }^{1}$ Corresponding author; e-mail: mvmagr@ cid.csic.es. including 'Tsugaru' and 'Jonagold' apples, sweet cherry (Prunus avium L.) and tomato (Kondo et al., 1991; Kondo and Gemma, 1993; Martínez Madrid et al., 1996; Uthaibutra and Gemma, 1991), although in other fruit, such as 'Senshu' and 'Fuji' apples, pepper (Capsicum annиum L. var. аппиит) and sweet cherry, ABA concentrations do not change or even decrease during this period (Kondo et al., 1991; Kondo and Tomiyama, 1998; Serrano et al., 1995). Thus, the relationship between ABA, ethylene production, and maturation has not been clearly established.

The control for the onset of autocatalytic ethylene biosynthesis is not yet clear. It is well known that internal ethylene increases during maturation. However, there have been only a few reports of changes in ACC during fruit development while attached to the tree. Because ABA treatment has been shown to stimulate climacteric ethylene biosynthesis in 'Granny Smith' apple fruit (Lara and Vendrell, unpublished), the question arises whether initial events triggered by ABA may play a role in 'Granny Smith' apple maturation and ripening. Therefore, the objective of this study was to assess changes in ethylene biosynthesis and in endogenous ABA content during the preharvest period of 'Granny Smith' apple development. Endogenous levels of ABA, ACC, ethylene-forming capacity (EFC), ACC synthase (ACS) and ACC oxidase (ACO) proteins, and total protein patterns were monitored throughout the experimental period.

\section{Materials and Methods}

Plant material. 'Granny Smith' apple fruit from Vallfonda, Lleida, Spain, were collected at intervals of 7 to $14 \mathrm{~d}$ from $\approx 120 \mathrm{~d}$ after full bloom (DAFB) to their commercial harvest time $(\approx 200$ DAFB), and selected for uniformity of size and absence of defects. A sample of 10 fruit was taken from a row of trees at each harvesting date. Sampling was from 2 Aug. to 21 Oct. 1994. Pulp and peel tissue samples were taken for analysis immediately after harvest, frozen in liquid nitrogen, lyophilized, reduced to powder, and kept at $-80^{\circ} \mathrm{C}$ until processing. 
Endogenous aba CONCENTRATION. ABA concentration was determined according to the methods of Carrasquer et al. (1990), with slight modifications. Briefly, samples $(500 \mathrm{mg})$ of homogenized lyophilized tissue were extracted for $36 \mathrm{~h}$ in the dark at $4{ }^{\circ} \mathrm{C}$, with gentle agitation, in $200 \mathrm{~mL}$ methanol : $6.8 \mathrm{~mm}$ phosphoric acid $(80: 20, \mathrm{v} / \mathrm{v})$ and $100 \mathrm{mg} \cdot \mathrm{L}^{-1}$ 2,6-di-tert-butyl-4-methylphenol $(\mathrm{BHT})$ as an antioxidant. The filtrate was adjusted with concentrated sodium bicarbonate to $\mathrm{pH} 8.5$, and methanol removed under vacuum at $35^{\circ} \mathrm{C}$. The aqueous phase was prepurified by loading onto a SepPak $\mathrm{C}_{18}$ cartridge (Waters Corp., Milford, Mass.). The eluted fraction was lyophilized and stored at $-20^{\circ} \mathrm{C}$ until injection into a high-performance liquid chromatography (HPLC) system (Applied Biosystems Inc., Foster City, Calif.) for ABA separation and further quantification. Two columns were used: a Brownlee RP-18, $5 \mu \mathrm{m}$ $(220 \times 4.6 \mathrm{~mm}$ i.d.) stainless-steel column (Brownlee, Mississauga, Ont. Canada), and a Tracer Extrasil Sax, $5 \mu \mathrm{m}(250 \times 4.6 \mathrm{~mm}$ i.d. $)$ stainless-steel column (Teknokroma, Sant Cugat del Vallès, Spain). Both columns were operated at room temperature $\left(\approx 20^{\circ} \mathrm{C}\right)$. The detector was set at $260 \mathrm{~nm}$, and eluent was delivered at a flow rate of $1 \mathrm{~mL} \cdot \mathrm{min}^{-1}$ according to a gradient program (for details, see Carrasquer et al., 1990). The eluents used were methanol and $6.8 \mathrm{~mm}$ phosphoric acid for the RP-18 column, and methanol and $2 \mathrm{~mm}$ acetic acid for the SAX column. Results are means of three individual fruit, expressed as nmol ABA/g dry weight.

Ethylene Production. Four apples per sampling date were placed individually in 350-mL containers aerated continuously with $\approx 1 \mathrm{~L} \cdot \mathrm{h}^{-1}$ of humidified air. For ethylene analysis, $2-\mathrm{mL}$ gas samples were taken periodically from the effluent air and injected into a gas chromatograph (model 5890; Hewlett Packard Co., Palo Alto, Calif.) equipped with an activated alumina column $(2 \mathrm{~m} \times 4 \mathrm{~mm}$ i.d., Supelco Inc., Bellefonte, Pa.) and a flame ionization detector. Operating conditions were as follows: oven temperature $110^{\circ} \mathrm{C}$, injector temperature $120^{\circ} \mathrm{C}$, detector temperature $180^{\circ} \mathrm{C}$, nitrogen carrier gas $40 \mathrm{~mL} \cdot \mathrm{min}^{-1}$. Results for ethylene are expressed as $\mu \mathrm{L} \cdot \mathrm{kg}^{-1} \cdot \mathrm{h}^{-1}$.

ETHYLENE-FORMING CAPACITY. EFC of pulp and peel tissues was determined in vivo by measuring the conversion of exogenous ACC to ethylene as described previously (Lara and Vendrell, 1998b). Samples ( $1 \mathrm{~g}$ fresh weight) of pulp and peel tissues from four apples were taken per sampling date. Cylinders of pulp tissue were removed radially with an $8 \mathrm{~mm}$ (i.d.) steel cork borer and cut into uniform discs $1 \mathrm{~mm}$ thick. Thin strips of peel were removed carefully with a fruit peeler. Samples were put in $20-\mathrm{mL}$ vials containing $3 \mathrm{~mL}$ incubation medium (0.4 M mannitol, $50 \mathrm{~mm}$ MES$\mathrm{KOH}$, pH 7.0 for pulp; 0.4 м mannitol, 10 mм MES-KOH, pH 6.1 for peel) in the presence of $5 \mathrm{~mm}$ ACC and $0.1 \mathrm{~mm}$ cycloheximide. Sealed flasks were then incubated at $20^{\circ} \mathrm{C}$ for $3 \mathrm{~h}$, and gas samples were taken for ethylene analysis by gas chromatography. Samples incubated in the absence of ACC served as controls. Data for ethylene are presented as nmol. $\mathrm{g}^{-1} \cdot \mathrm{h}^{-1}$.

ACC AND MALONYL-ACC (MACC) CONCENTRATion. About $0.15 \mathrm{~g}$ (pulp) or $0.22 \mathrm{~g}$ (peel) of lyophilized tissue from four apples was taken per sampling date to analyze for both ACC and MACC contents. Samples were extracted under reflux for 15 min with $80 \%$ ethanol, which was removed under vacuum at $40^{\circ} \mathrm{C}$. Free ACC was measured directly on the aqueous extract according to methods of Lizada and Yang (1979). Total ACC concentration was determined from the aqueous extract, hydrolyzed previously with $7.2 \mathrm{M} \mathrm{HCl}$ at $100^{\circ} \mathrm{C}$ for $3 \mathrm{~h}$, following procedures described by Hoffman et al. (1982). MACC was taken as the difference between total and free ACC concentrations. Results for ACC are presented in $\mathrm{nmol} \cdot \mathrm{g}^{-1}$ fresh weight.
TOTAL PROTEIN EXTRACTION AND SDS-PAGE. Total soluble proteins of pulp and peel tissues were extracted and separated by SDS-PAGE according to Domínguez-Puigjaner et al. (1992), with modifications. Homogenized lyophilized tissue $(150 \mathrm{mg})$ was extracted with $1 \mathrm{~mL}$ buffer $(0.25 \mathrm{~m}$ Tris-HCl, $\mathrm{pH} 8.4,0.2 \mathrm{~m}$ glycine, $0.4 \%$ (w/v) SDS, $10 \%$ (v/v) 2-mercaptoethanol). After centrifugation, proteins in the supernatant were precipitated with $15 \%$ trichloroacetic acid and washed in methanol : $1 \mathrm{~m}$ ammonium acetate $(90: 10, \mathrm{v} / \mathrm{v})$, vacuum dried, and stored at $-80^{\circ} \mathrm{C}$ until electrophoretical separation. For SDS-PAGE, the pellet was dissolved in $50 \mu \mathrm{L}$ sample buffer (60 mm Tris-HCl, pH 6.8, 10\% (v/v) glycerol, $2 \%$ (w/v) SDS, $5 \%(\mathrm{v} / \mathrm{v}) 2$-mercaptoethanol). Aliquots $(20 \mu \mathrm{L})$ were loaded in each lane for SDS-PAGE at $32 \mathrm{~mA}$ on a $15 \%$ slab gel $(1.5 \times 160 \times 160$ $\mathrm{mm}$ ) according to procedures of Laemmli (1970). Standard molecular mass markers (Sigma, St. Louis, Mo.) were used. Protein concentrations were measured by the Bradford (1976) method, with modifications (Bio-Rad Protein Assay), using BSA as a standard.

IMmunOBLOTTING. Separated polypeptides were blotted onto a PVDF membrane (Immobilon P, Millipore Corp., Bedford, Mass.) using a semidry electrophoretic transfer cell (Bio-Rad Laboratories, Hercules, Calif.) according to recommendations of the manufacturer, and immunodetection was performed using routine procedures (Ausubel et al., 1997). Antibodies raised against ACC oxidase were used to monitor accumulation of ACC oxidase (ACO) protein in our samples. Total soluble protein extracts from pulp or peel of fully ripe ‘Granny Smith' fruit were taken as a positive control. Blots were developed with ECL Western Blotting Detection Kit (Amersham Life Science Ltd., Buckinghamshire, United Kingdom), and signals were quantified using a Lumi Analyst 2.0 program (Boehringer Mannheim GmbH/ Media Cybernetics LP).

IMMUNOPRECIPITATION OF ACS PROTEIN. Immunoprecipitation assays were undertaken to assess the presence or absence of ripening-related ACC synthase (ACS) in our samples, according to published protocols (Ausubel et al., 1997). Lyophilized homogenized tissue $(150 \mathrm{mg})$ was incubated in $1 \mathrm{~mL}$ lysis buffer $(0.5 \%$ Triton X-100, $1 \mathrm{~mm}$ phenylmethylsulfonyl fluoride, $5 \mathrm{~mm}$ iodoacetamide, and 0.2 TIU aprotinin/mL, in TSA solution) for $1 \mathrm{~h}$ at $4{ }^{\circ} \mathrm{C}$. After centrifugation, the supernatant was precleared with a 1:1 (v/v) slurry of CNBr-activated Sepharose (Pharmacia Biotech, Uppsala, Sweden) in TSA solution (0.01 M Tris-HCl, pH 8.0, 0.14 $\mathrm{MNaCl}$, and $0.025 \% \mathrm{NaN}_{3}$ ) at $4{ }^{\circ} \mathrm{C}$ for $1 \mathrm{~h}$ to precipitate nonspecifically bound materials. The nonprecipitating fraction was then incubated for $1 \mathrm{~h}$ at $4{ }^{\circ} \mathrm{C}$, with slow rotation, with an appropriate dilution of monoclonal antibody raised against ripening-related apple ACS previously coupled to a CNBr-activated Sepharose slurry in TSA. The complex antigen-antibody-Sepharose was then pelleted by centrifugation at $6,500 \mathrm{~g}_{\mathrm{n}}$ for $15 \mathrm{~min}$, and the supernatant was discarded. The pellet was washed twice with $0.1 \%$ Triton X-100 in TSA, then with TSA, and finally with $0.05 \mathrm{M}$ Tris- $\mathrm{HCl}, \mathrm{pH}$ 6.8. After this washing procedure, the sample was resuspended in $30 \mu \mathrm{L} \mathrm{SDS-}$ PAGE sample buffer, heated at $90^{\circ} \mathrm{C}$ for $5 \mathrm{~min}$, centrifuged at 6,500 $g_{\mathrm{n}}$ for $1 \mathrm{~min}$ to pellet Sepharose, and loaded for analysis onto a $12 \%$ gel in a Mini-Protean II apparatus (Bio-Rad), according to the manufacturer's instructions. Samples from pulp or peel of fully ripe 'Granny Smith' fruit, processed in a similar way, were taken as a positive control. Standard molecular mass markers (Sigma) were used. Separated polypeptides were fixed and silver-stained using a commercially available kit (Sigma) according to the manufacturer's protocol.

Statistical anAlysis. Combined analyses of variance were performed across sampling times for comparison between tissues (peel and pulp), except for ABA concentration in which case 
separate analyses were carried out for each tissue. F-protected LSD values at $P=0.05$ were calculated to assess time-course evolution of the parameters monitored. All analyses were done according to standard SAS-STAT procedures (SAS Institute, Inc., 1987).

\section{Results}

Changes in endogenous aba during maturation. Large differences in endogenous ABA concentrations were found between peel and pulp tissues during the experimental period (Fig. 1), with ABA levels in the peel being 40-fold greater than those in the pulp. The highest concentration $\left(\approx 3.3 \mathrm{nmol} \cdot \mathrm{g}^{-1} \mathrm{dry}\right.$ weight $)$ in the peel occurred at $\approx 150 \mathrm{DAFB}$, and decreased thereafter as commercial harvest date approached. ABA concentration in the pulp increased from $\approx 160$ DAFB (mid-September), although to much lower levels than those in the peel, but decreased again by the time of commercial harvest.

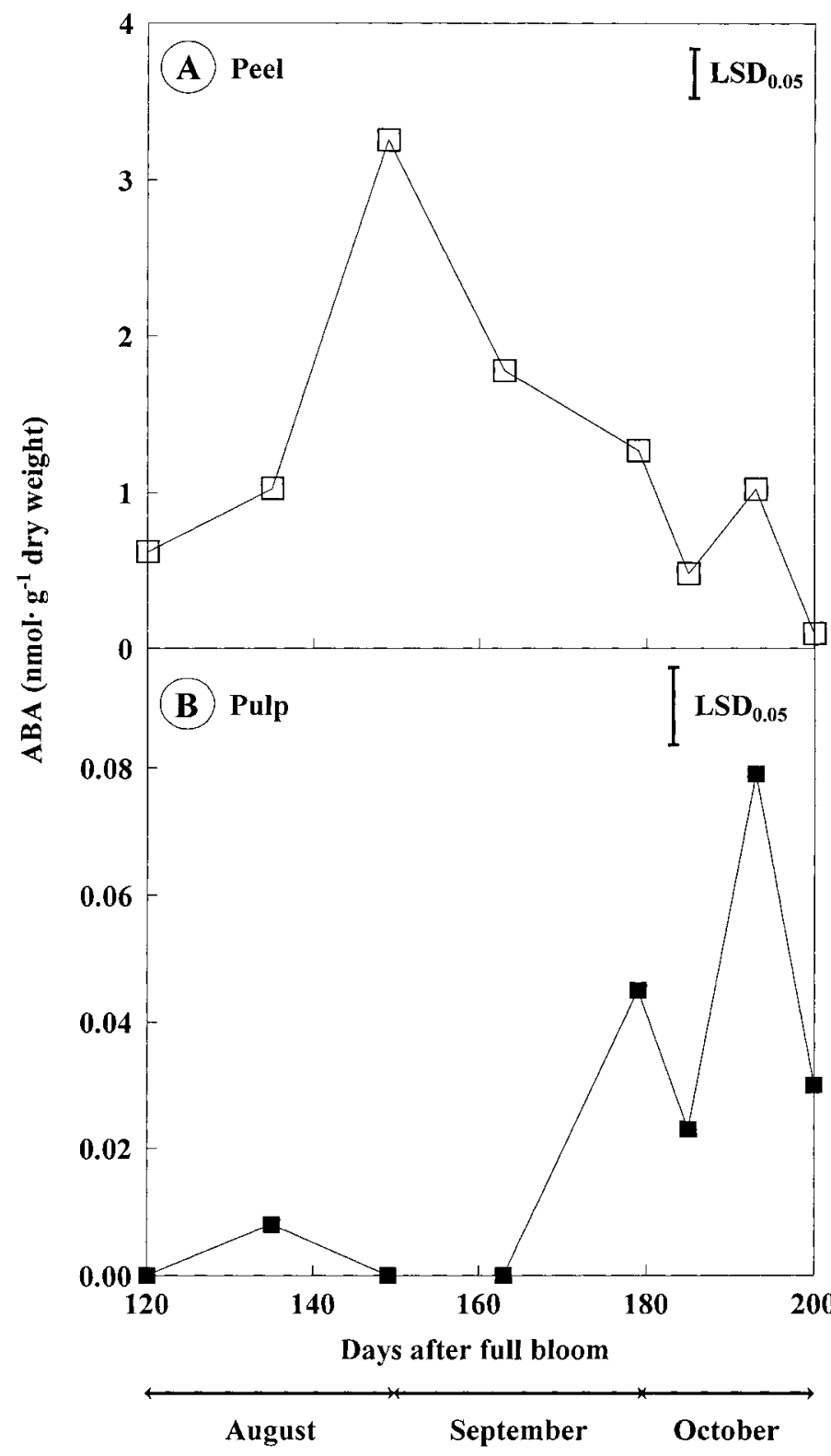

Fig. 1. Endogenous ABA concentrations in (A) peel and (B) pulp of 'Granny Smith' apples during the preharvest period. Values represent means of three replications.
Changes IN EFC AND IN ACo Protein AbUndance. EFC in the peel showed no large changes during fruit development (Fig. 2A), whereas an EFC peak in the pulp occurred at $\approx 160 \mathrm{DAFB}$, before the rise observed in ABA concentration. Because this single peak of EFC in pulp tissue represented a time point in a single season, EFC measurements were repeated the following year. The peak was observed again by about the same time as in the preceding season, although at much lower levels (data not presented). The peak in EFC was not paralleled by any change in ACO protein abundance either in pulp or in peel, as reflected by results of immunoblotting (Fig. 2B). Although the antibody used immunoreacted against one polypeptide extracted from fully ripe fruit, which served as a positive control, the same antibody failed to detect ACO protein on preclimacteric fruit extracts, suggesting the protein must be present in very low quantities throughout fruit maturation.

Changes IN ACC AND MACC CONTENT AND PRESENCE OF RIPENINGRELATED ACS PROTEIN. ACC contents in pulp and peel tissues did not differ notably during fruit development. In both tissues there was a slight but steady decrease during August and early September, followed by a sharp increase after $\approx 160$ DAFB (Fig. 3A). MACC followed similar trends to ACC (Fig. 3B). These increases took place concomitantly with the rise in endogenous $\mathrm{ABA}$ content in the
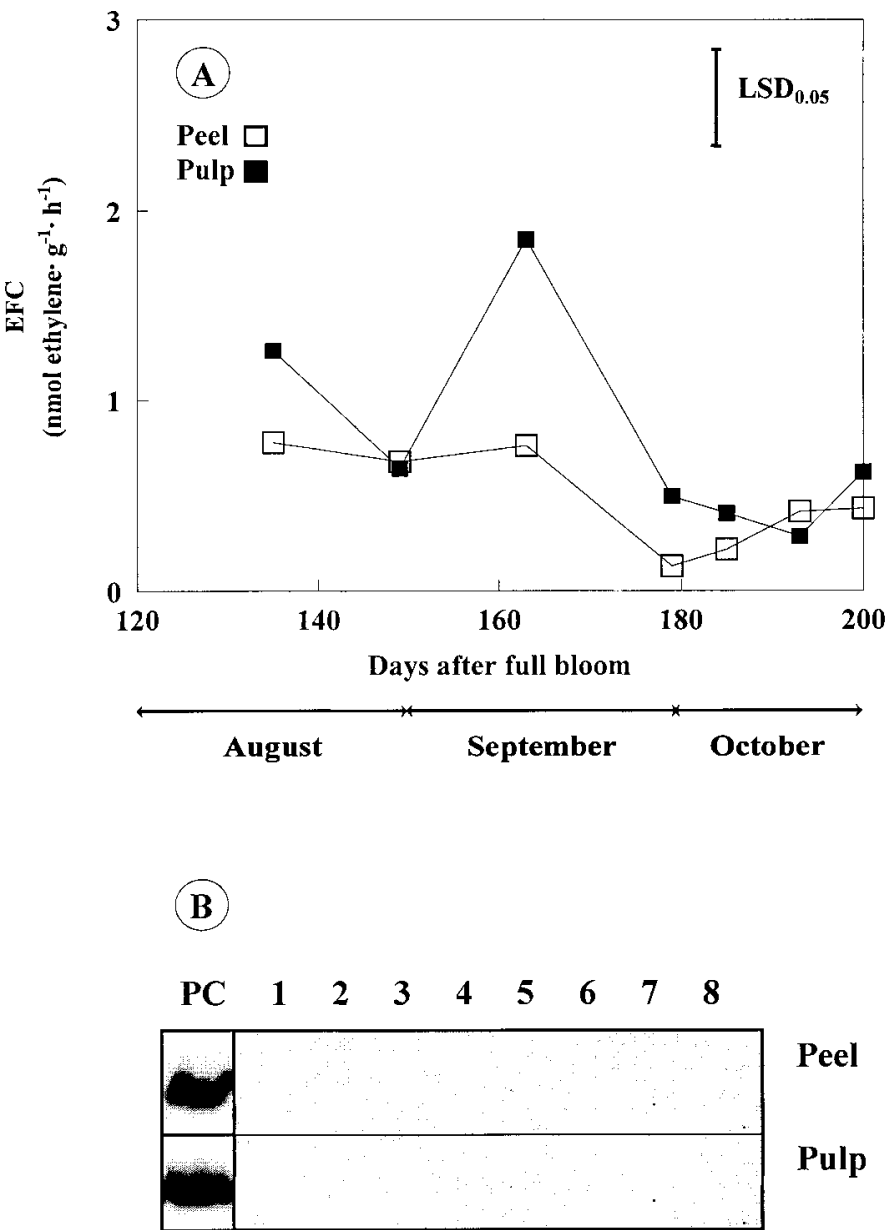

Fig. 2. (A) Ethylene forming capacity in peel and pulp of 'Granny Smith' apples during the preharvest period. Values represent means of four replicates. (B) Immunoblot of ACC oxidase protein in peel and pulp of 'Granny Smith' apples during the preharvest period. Lane PC = positive control. Lanes 1-8 = fruit harvested at $120(\mathbf{1}), 135(\mathbf{2}), 149(\mathbf{3}), 163(\mathbf{4}), 179(\mathbf{5}), 185(\mathbf{6}), 193(\mathbf{7})$, and 200 (8) days after full bloom. 
pulp(Fig. 1B). In addition, fruit harvested at $\approx 185 \mathrm{DAFB}$, after ACC accumulation had begun, displayed higher ethylene production rates after harvest than those collected at a more immature stage (Table 1), yet production was significantly higher only 3 weeks after harvest time. However, immunoprecipitation assays failed to detect ripening-related ACS protein in preclimacteric fruit, although the antibody used was efficient in precipitating the protein in fully ripe fruit (data not presented).

Changes IN PROtein PATTERN. Some variation was found in the protein pattern of the peel (Fig. 4A) during fruit maturation, with increases in polypeptides of apparent molecular weights of 69,60 , 51,18 , and $16 \mathrm{kD}$ and decreases in polypeptides of $\approx 71$ and $17 \mathrm{kD}$, although major differences were observed in polypeptides of 18 and $17 \mathrm{kD}$. There was a preferential accumulation of polypeptides in the pulp of $\approx 71,64,61,51,42,31,24$, and $18 \mathrm{kD}$ throughout the maturation process. Interestingly, four polypeptides with apparent molecular weights of $47,46,35$, and $25 \mathrm{kD}$ were found to be induced transiently in the pulp at $\approx 150$ DAFB (Fig. 4B), concomitantly with the peak of endogenous $\mathrm{ABA}$ in the peel and before the rises in $\mathrm{ABA}$, $\mathrm{ACC}$, and EFC in the pulp.

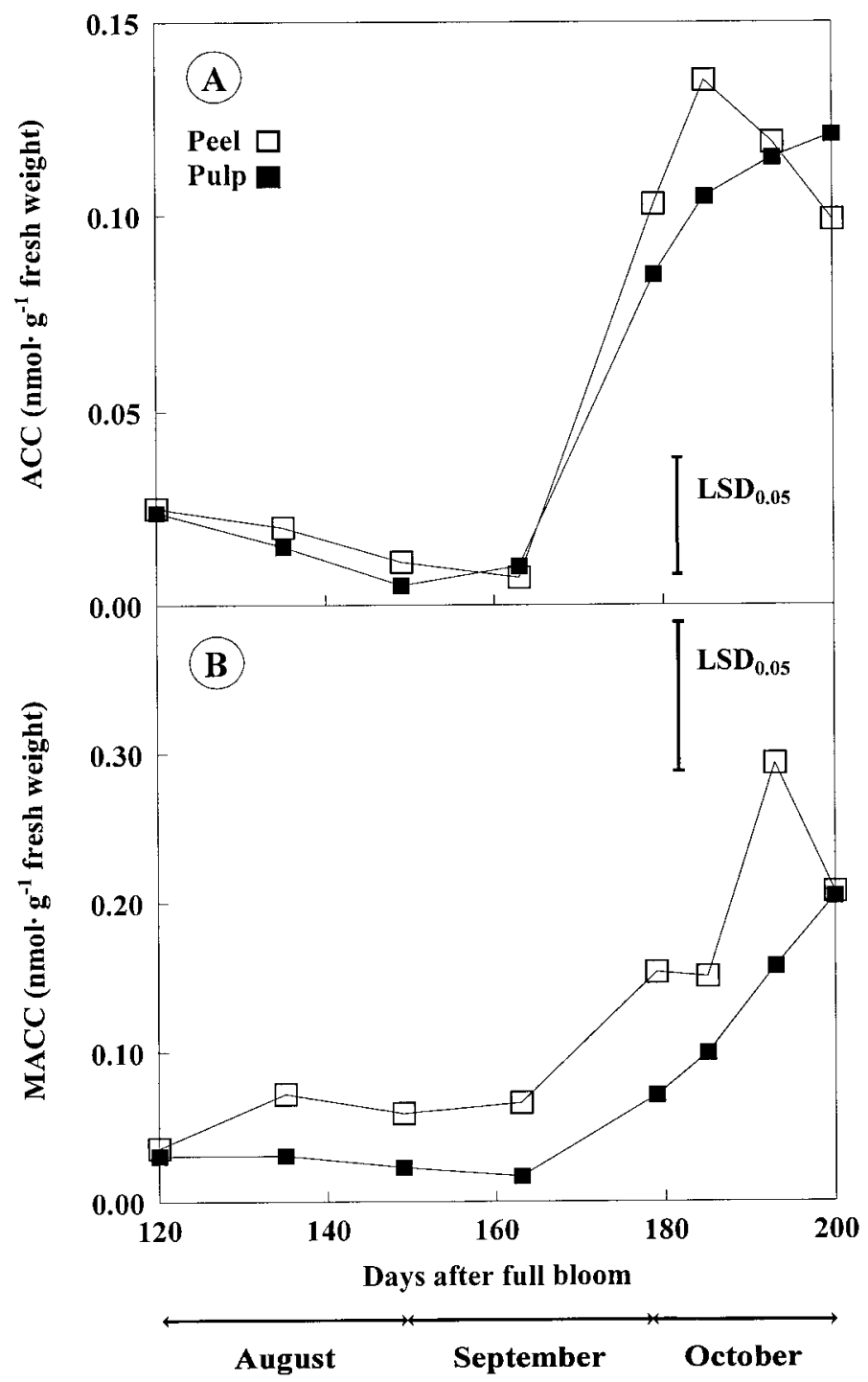

Fig. 3. (A) ACC and (B) MACC concentrations in peel and pulp of 'Granny Smith' apples during the preharvest period. Values represent means of four replications.

\section{Discussion}

The main proteins extracted from peel and pulp tissues (Fig. 4) remained present throughout maturation of 'Granny Smith' apples, and there was little change in total protein concentration in both peel and pulp tissues during maturation, which averaged $\approx 555$ and 510 $\mu \mathrm{g} \cdot \mathrm{mL}^{-1}$, respectively (data not presented). Some polypeptides were induced transiently in the pulp (Fig. 4B), concomitantly with an ABA peak in the peel (Fig. 1A). The transient presence of these polypeptides is not likely to be artifactual, for extraction and SDSPAGE of the samples were performed several times with similar results. The function of these polypeptides remains unknown, further studies being necessary for identification and characterization. Because their appearance was concomitant with an ABA peak in the peel, and they were not found in later stages with lower ABA contents, the possibility arises of a connection between both events. Nevertheless, it should be noticed they occurred in two different tissues, and that no data recorded in this study support ABA translocation taking place from peel to pulp, although redistribution of ABA within cells and organs has been observed (reviewed in Zeevaart and Creelman, 1988). There have been some reports on ABA-altered gene expression. Polypeptides of 19, 21, and $47 \mathrm{kD}$ were induced $8 \mathrm{~h}$ after ABA treatment in bromegrass (Bromus inermis Leyss) cultured cells (Robertson et al., 1987), whereas increases in 31 and $72 \mathrm{kD}$ polypeptides were found in ABA treated cultures after $36 \mathrm{~h}$. ABA treatment altered both polypeptide and translatable mRNA populations, some of them transiently, during induction of cold hardiness in white potato (Solanum commersonii Dun.) (Tseng and Li, 1991). When cycloheximide was added, it completely inhibited development of ABA-induced frost hardiness (Chen et al., 1983). Similarly, dehydration-induced synthesis of ABA in excised pea (Pisum sativum L.) plants requires nuclear gene transcription (Guerrero and Mullet, 1986), and gene activation is involved in proline accumulation in response to ABA in barley (Hordeum vulgare L.) leaves (Stewart et al., 1986).

Endogenous ABA concentration in the peel of 'Granny Smith' apples is much higher than that reported for other apple cultivars (Kondo et al., 1991; Uthaibutra and Gemma, 1991). The physiological relevance of such a high level of endogenous ABA in the peel of 'Granny Smith' apples is unclear. The ABA peak found at $\approx 150$ DAFB coincided temporally with the initiation of chlorophyll degradation, which dropped more than $25 \%$ as compared to the previous sampling date (data not presented). Chlorophyll concentration decreased from $158 \mu \mathrm{g} \cdot \mathrm{g}^{-1}$ fresh weight at $120 \mathrm{DAFB}$ to $\approx 81$ $\mu \mathrm{g} \cdot \mathrm{g}^{-1}$ fresh weight at commercial harvest. For some red-skinned apple cultivars and for some nonclimacteric fruit, a relationship of endogenous ABA to anthocyanin content has been reported (Kondo and Gemma, 1993; Kondo et al., 1991). This is not the case for 'Granny Smith' apples, which remain bright green throughout

Table 1. Ethylene production rates per $\mathrm{kg}$ fresh weight $\left(\mu \mathrm{L} \cdot \mathrm{kg}^{-1} \cdot \mathrm{h}^{-1}\right)$ of 'Granny Smith' apples harvested at three different maturity stages [days after full bloom (DAFB)]. Data are the means for four individual fruit \pm SE.

\begin{tabular}{lccc}
\hline \hline Days after & \multicolumn{3}{c}{ Maturity stage (DAFB) } \\
\cline { 2 - 4 } fruit harvest & 120 & 163 & 185 \\
\hline $\mathbf{0}$ & $\mathrm{ND}^{\mathrm{z}}$ & $\mathrm{ND}$ & $\mathrm{ND}$ \\
$\mathbf{7}$ & $4.2 \pm 0.2$ & $5.7 \pm 0.3$ & $5.4 \pm 0.3$ \\
$\mathbf{1 4}$ & $7.1 \pm 0.2$ & $7.9 \pm 0.4$ & $8.7 \pm 0.4$ \\
$\mathbf{2 1}$ & $13.1 \pm 0.5$ & $14.4 \pm 0.7$ & $33.1 \pm 1.6$
\end{tabular}

${ }_{\mathrm{zND}}=$ nondetectable 
development, ripening, and storage; however, this point explains why $\mathrm{ABA}$ concentration in the peel reaches $\approx 40$ times that in the pulp, since $\mathrm{ABA}$ accumulates mainly in the chloroplasts (Zeevaart and Creelman, 1988).

Endogenous ABA concentration in the pulp of 'Granny Smith'

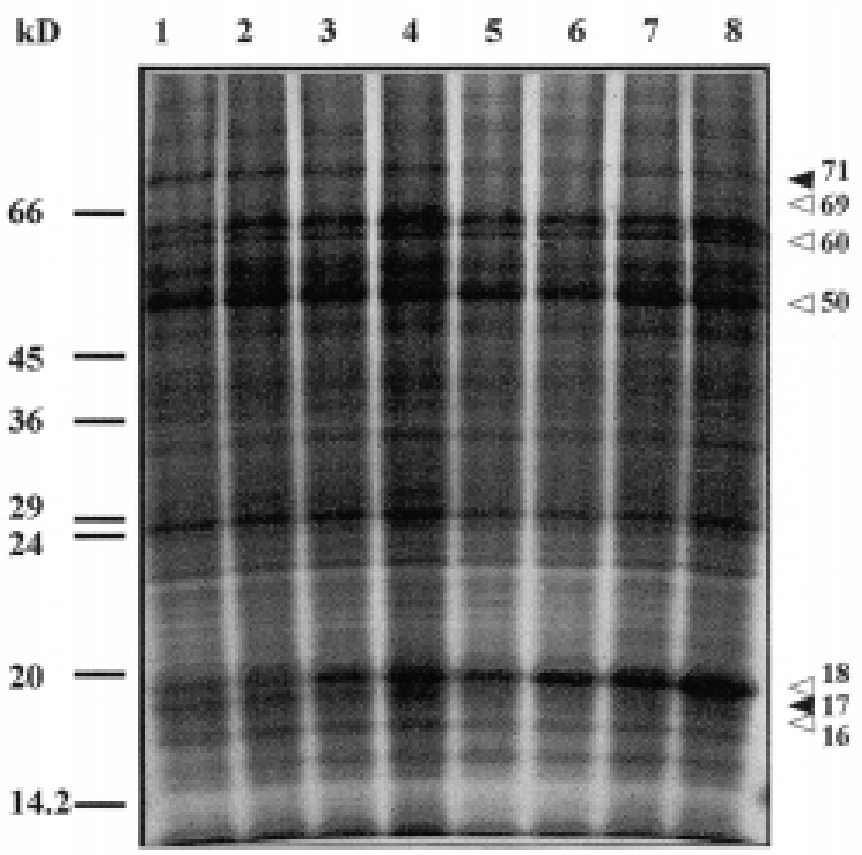

B

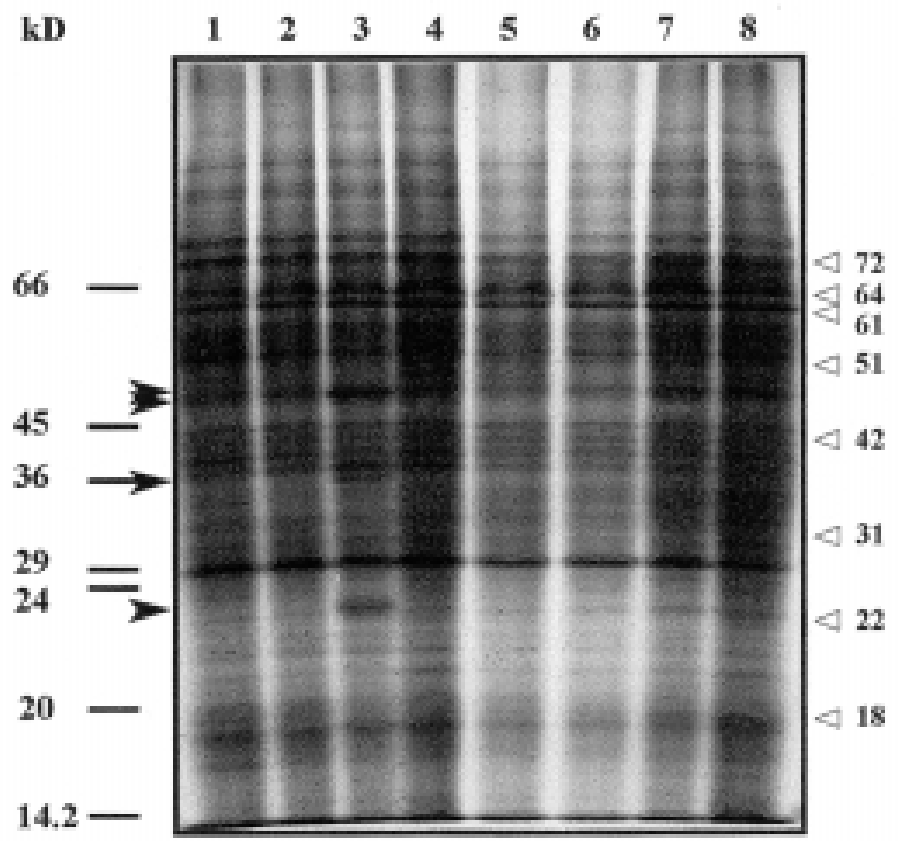

Fig. 4. SDS-PAGE of total polypeptides extracted from (A) peel and (B) pulp of 'Granny Smith' apple fruit. Lanes 1 to $8=$ samples at different maturity stages: 120 (1), 135 (2), 149 (3), 163 (4), 179 (5), 185 (6), 193 (7), and 200 (8) days after full bloom. The molecular weight markers are shown on the left. White arrows show polypeptides that increase during the preharvest period; black arrows show polypeptides that decrease. Black symbols on the left indicate transiently induced polypeptides on lane 3 . Gels were stained with Coomassie blue. apples was similar to previous reports on other apple cultivars, such as 'Red Winesap' (Vendrell andBuesa, 1989), 'Jonagold' (Uthaibutra and Gemma, 1991) and 'Tsugaru' (Kondo et al., 1991), in which a lag period with very low ABA concentrations was followed by a sharp rise occurring 1 to 2 months before the commercial harvest date. Moreover, in the latter case, a parallel increase in ACC and internal ethylene concentrations was observed at the same time as the increase in endogenous ABA (Kondo et al., 1991). Similar results were found in the present study, where a noticeable rise in both ACC and MACC (Fig. 3A and B) and in ethylene production (Table 1) was displayed concomitantly with increasing ABA concentrations in the pulp tissue. A strong correlation $\left(r^{2}=0.84\right)$ was found between endogenous ABA and ACC levels. Although many changes occur during this period, which may coincide temporally with $\mathrm{ABA}$ accumulation, the possibility of a direct relationship between ABA and ACC accumulation is supported further by the fact that $\mathrm{ABA}$ treatment has been reported to enhance ethylene production in different plant tissues of several species (Brady, 1987; Gómez Cadenas et al., 1996; Riov et al., 1990; Tari and Nagy, 1996; Vendrell and Buesa, 1989). In contrast, no similar relationship was found for the peel tissue, possibly indicating differentially regulated ethylene biosynthesis in peel and pulp tissues, as previously suggested for 'Granny Smith' apples (Lara and Vendrell, 1998b) and 'Passe-Crassane' pears (Pyrus communis L.) (Lara and Vendrell, 1998a). Ethylene and carbon dioxide production, fruit firmness, and pigmentation have been used as markers to identify maturity stages of climacteric fruit, but the physiological changes occurring during apple fruit development differ among cultivars (Kondo et al., 1991; Mansour et al., 1986; Uthaibutra and Gemma, 1990 and 1991). Enhancement of ACC synthesis may be the point signaling the transition from preclimacteric immature to preclimacteric mature fruit. If endogenous ABA was involved in ACC synthesis enhancement, it could be used as a maturity stage indicator in 'Granny Smith' apples.

No ripening-related ACS protein was found at any stage during the experimental period, although the antibody used was able to immunoprecipitate the protein in fully ripe 'Granny Smith' tissues. Because an increase in ACC concentration was observed by $\approx 160$ DAFB (Fig. 3A), it becomes evident that some ACS activity must have been present, and therefore failure to detect the protein may be

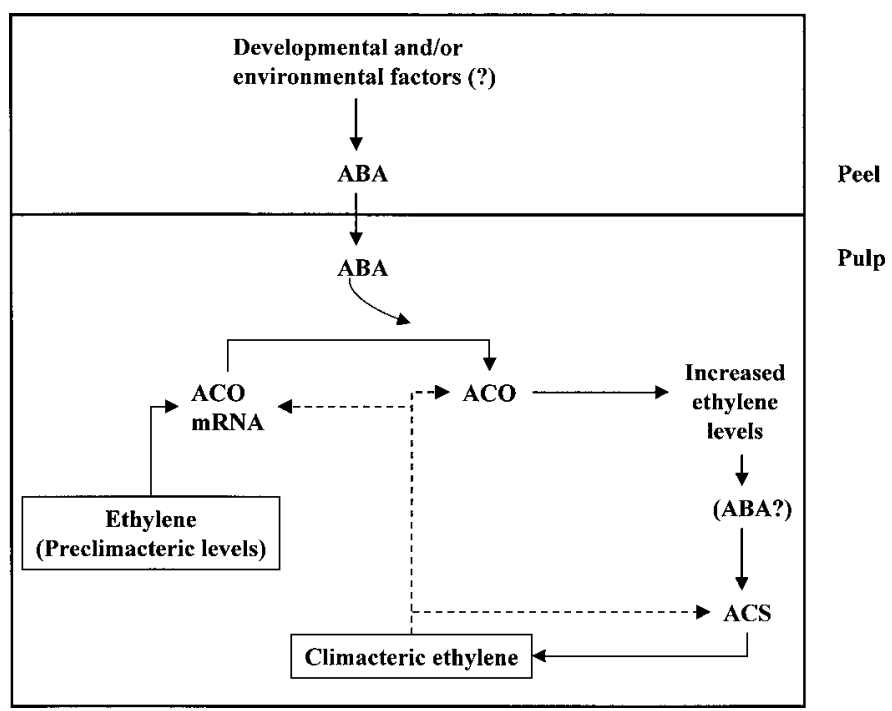

Fig. 5. A proposed model for the interaction between ethylene and ABA during maturation of 'Granny Smith' fruit. 
attributed to different causes. First, ACC synthase is known to exist in very low abundance and to be unstable (Yang and Dong, 1993). If amounts of the protein are very low during the maturation period, this might explain why it could not be detected during the experimental time. The rise in ACC concentration might be due either to an enhancement of the activity of the protein present, or to an increase in ACS abundance, which was not sufficient to render the protein detectable. Second, ACC synthase exists in isoforms that are derived from different genes and that are different immunologically (Yang and Dong, 1993). Thus, failure to detect the ripening-related isoform in spite of moderate ACC concentrations could be an indication that a different ACS is being expressed during maturation. This possibility is supported by the fact that the antibody used, raised against apple ripening-related $\mathrm{ACS}$, was able to detect the protein in fully ripe fruit (results not presented). Third, there is some evidence (Lara and Vendrell, submitted) that an ABA treatment advances accumulation of ripening-related ACS in preclimacteric 'Granny Smith' apples. Therefore, endogenous ABA concentrations present during maturation might not be enough to induce expression of the gene. Actually, ABA concentrations in the pulp of fully ripe 'Granny Smith' fruit, in which detectable levels of ACSrelated polypeptides were found, were $\approx 10$-fold those shown in Fig. 1 (data not presented).

No ACO protein was detectable throughout the experimental period considered (Fig. 2B), indicating that constitutive levels of the enzyme are very low, although a peak in EFC in the pulp was detected (Fig. 2A), before the increases in endogenous ABA (Fig. 1B) and ACC (Fig. 3A). It has been postulated that during the ripening process both expression of the gene and development of activity of ACC oxidase precede those of ACC synthase (Yang and Dong, 1993). This series of events is in accordance with results reported herein, indicating that ethylene production by preclimacteric fruit is limited in part by a reduced ability to convert ACC to ethylene, in addition to a restriction in ACS presence and/or activity. Nevertheless, low activities may be enough for the intrinsic requirement of fruit ripening. It has been reported recently (Lara and Vendrell, submitted) that an ABA treatment induces accumulation of ACO protein in very immature 'Granny Smith' apples. A hypothesis integrating these data is proposed (Fig. 5). The model proposes that basal endogenous ethylene levels present in the pulp during the preclimacteric could be responsible for accumulation of ACO transcript (Dong et al., 1992). The transcript would be translated in response to increased ABA concentrations in the peel (Fig. 1A), which would be translocated to the pulp. The denovosynthesized ACO protein would cause an increase in endogenous ethylene levels, which in turn would enhance expression of ACC synthase, either directly or through a modification of ABA levels. However, this hypothesis remains to be tested, and evidence supporting ABA translocation from peel to pulp is lacking. Additionally, peel data do not support this hypothesis, which may suggest a different regulation of ethylene biosynthesis in this tissue.

\section{Literature Cited}

Ausubel, F.M., R. Brent, R.E. Kingston, D.D. Moore, J.G. Seidman, J.A. Smith, and K. Struhl. 1997. Current protocols in molecular biology. Wiley, New York.

Biggs, M.S., R.W. Harriman, and A.K. Handa. 1986. Changes in gene expression during tomato fruit ripening. Plant Physiol. 81:395-403.

Bozak, K.R., H. Yu, R. Sirevag, and R.E. Christoffersen. 1990. Sequence analysis of ripening-related cytochrome P-450 cDNAs from avocado fruit. Proc. Natl. Acad. Sci. USA 69:1408-1412.

Bradford, M.M. 1976. A rapid and sensitive method for the quantitation of microgram quantities of protein utilizing the principle of protein-dye binding. Anal. Biochem. 72:248-254.

Brady, C.J. 1987. Fruit ripening. Annu. Rev. Plant Physiol. 38:155-178. Callahan, A., P. Morgens, and E. Walton. 1989. Isolation and in vitro translation of RNAs from developing peach fruit. HortScience 24:356358.

Carrasquer, A.M., I. Casals, and L. Alegre. 1990. Semi-automated method for the determination of ABA in crude plant extracts. J. Chromatogr. 503:459-465.

Chen, H.H., P.H. Li, and M.L. Brenner. 1983. Involvement of abscisic acid in potato cold acclimation. Plant Physiol. 71:362-365.

Davies, K.M. and D. Grierson. 1989. Identification of cDNA clones for tomato (Lycopersicon esculentum Mill.) mRNAs that accumulate during fruit ripening and leaf senescence in response to ethylene. Planta 179:7380.

Díaz Miguel, M. 1995. Inhibition of germination and ethylene production by abscisic acid in Cicer arietinum seeds and its reversal by ethrel and partial reversal by spermine. Agrochimica 39:10-17.

Domínguez-Puigjaner, E., M. Vendrell, and M.D. Ludevid. 1992. Differential protein accumulation in banana fruit during ripening. Plant Physiol. 98:157-162.

Dong, J.G., J.C. Fernández-Maculet, and S.Y. Yang. 1992. Purification and characterization of ACC oxidase from ripe apple fruit. Proc. Natl. Acad. Sci. USA 89:9789-9793.

Gallardo, M., A. Matilla, and I.M. Sánchez Calle. 1992. Effects of spermine, abscisic acid and temperature upon ethylene production in Cicer arietinum seeds. Plant Physiol. Biochem. 30:19-27.

Gómez Cadenas, A., F.R. Tadeo, M. Talón, and E. Primomillo. 1996. Leaf abscission induced by ethylene in water-stressed intact seedlings of 'Cleopatra' mandarin requires previous abscisic acid accumulation in roots. Plant Physiol. 112:401-408.

Guerrero, F. and J.E. Mullet. 1986. Increased abscisic acid biosynthesis during plant dehydration requires transcription. Plant Physiol. 80:588591.

Hoffman, E.N., S.F. Yang, and T. McKean. 1982. Identification of MACC as a major conjugate of ACC, an ethylene precursor. Biochem. Biophys. Res. Comm. 104:765-770.

Kondo, S. and H. Gemma. 1993. Relationship between ABA content and maturation of the sweet cherry. J. Jpn. Soc. Hort. Sci. 62:63-68.

Kondo, S. and A. Tomiyama. 1998. Changes of free and cojugated ABA in the fruit of 'Satohnishiki' sweet cherry and the ABA metabolism after application of (s)-(+)-ABA. J. Hort. Sci. Biotechol. 73:467-472.

Kondo, S., J. Uthaibutra, and H. Gemma. 1991. Comparison of ACC, abscisic acid and anthocyanin content of some apple cultivars during fruit growth and maturation. J. Jpn. Soc. Hort. Sci. 60:505-511.

Laemmli, U.K. 1970. Cleavage of structural proteins during the assembly of the head of bacteriophage T4. Nature 227:680-685.

Lara, I. and M. Vendrell. 1998a. ACC oxidase activation by cold storage on 'Passe-Crassane' pears: Effect of calcium treatment. J. Sci. Food Agr. 76:421-426.

Lara, I. and M. Vendrell. 1998b. Relationships between ethylene, abscisic acid and quality during postharvest storage of 'Granny Smith' apples. Postharvest Biol. Technol. 13:11-18.

Lay-Yee, M., D. DellaPenna, and G.S. Ross. 1990. Changes in mRNA and protein during ripening in apple fruit (Malus domestica Borkh. cv. Golden Delicious). Plant Physiol. 94:850-853.

Lincoln, J.E., S. Cordes, E. Read, and R.L. Fischer. 1987. Regulation of gene expression by ethylene during Lycopersicon esculentum (tomato) fruit development. Proc. Natl. Acad. Sci. USA 84:2793-2797.

Lizada, M.C.C. and S.F. Yang. 1979. A simple and sensitive assay for ACC. Anal. Biochem. 100:140-145.

Lu, G., H. Liang, and Z. Lu. 1992. Metabolism of ribonucleic acid and protein in ripening apple fruits. J. Plant Physiol., 139:569-573.

Mansour, R., A. Latché, V. Vaillant, J.C. Pech, and M.S. Reid. 1986. Metabolism of ACC in ripening apple fruits. Physiol. Plant. 66:495-503. Martínez Madrid, M.C., M. Serrano, F. Riquelme, and F. Romojaro. 1996. Polyamines, abscisic acid and ethylene production in tomato fruit. Phytochemistry 43:323-326.

Olson, D.C., J.A. White, R. Edelman, N. Harkins, and H. Kende. 1991. 
Differential expression of two genes for ACC synthase in tomato fruits. Proc. Natl. Acad. Sci. USA 8:5340-5344.

Riov, J., E. Dagan, R. Goren, and S.F. Yang. 1990. Characterization of abscisic acid-induced ethylene production in citrus leaf and tomato fruit tissues. Plant Physiol. 92:48-53.

Robertson, A.J., L.V. Gusta, M.J.T. Reaney, and M. Ishikawa. 1987. Protein synthesis in bromegrass (Bromus inermis Leyss) cultured cells during the induction of frost tolerance by abscisic acid or low temperature. Plant Physiol. 84:1331-1336.

SAS Institute, Inc. 1987. SAS/STAT guide for personal computers, Version 6th ed. SAS Inst., Inc., Cary, N.C.

Serrano, M., M.C. Martínez Madrid, F. Riquelme, and F. Romojaro. 1995. Endogenous levels of polyamines and abscisic acid in pepper fruits during growth and ripening. Physiol. Plant. 95:73-76.

Smith, C.J.S., A. Slater, and D. Grierson. 1986. Rapid appearance of an mRNA correlated with ethylene synthesis encoding a protein of molecular weight 35,000. Planta 168:94-100.

Speirs, J. and C.J. Brady. 1991. Modification of gene expression in ripening fruit. Austral. J. Plant Physiol. 18:519-532.

Stewart, C.R., G. Voetberg, and P.J. Rayapati. 1986. The effects of benzyladenine, cycloheximide, and cordycepin on wilting-induced abscisic acid and proline accumulations and abscisic acid- and salt-induced proline accumulation in barley leaves. Plant Physiol. 82:703-707.

Tari, I. and M. Nagy. 1996. Abscisic acid and ethrel abolish the inhibition of adventitious root formation of pacrobutrazol-treated bean primary leaf cuttings. Biol. Plant., 38:369-375.

Tseng, M.J. and P.H. Li. 1991. Changes in protein synthesis and translatable messenger RNA populations associated with ABA-induced cold hardiness in potato (Solanum commersonii). Physiol. Plant. 81:349-358.

Tucker, M.L. and G.G. Laties. 1984. Interrelationship of gene expression, polysome prevalence, and respiration during ripening of ethylene and/or cyanide-treated avocado fruit. Plant Physiol. 74:307-315.

Uthaibutra, J. and H. Gemma. 1990. Changes in ACC content and EFE activity of peel and pulp of 'Jonagold' apples during pre- and post-harvest periods. J. Jpn. Soc. Hort. Sci. 59:685-690.

Uthaibutra, J. and H. Gemma. 1991. Changes in abscisic acid content of peel and pulp of 'Jonagold' apples during pre- and post-harvest periods. J. Jpn. Soc. Hort. Sci. 60:443-448.

Vendrell, M. and C. Buesa. 1989. Relationship between abscisic acid content and ripening of apples. Acta Hort. 258:389-396.

Yang, S.F. and J.G. Dong. 1993. Recent progress in research of ethylene biosynthesis. Bot. Bul. Acad. Sin. 34:89-101.

Zeevaart, J.A.D. and R.A. Creelman. 1988. Metabolism and physiology of abscisic acid. Annu. Rev. Plant Physiol. Plant Mol. Biol. 39:439-473. 